\title{
A dual role of selenium in the growth control of seedlings of Stylosanthes humilis
}

\author{
Dimas Mendes Ribeiro, Ana Maria Mapeli, Werner Camargos Antunes, Raimundo Santos \\ Barros* $^{*}$
}

Depto de Biologia Vegetal, Universidade Federal de Viçosa, Viçosa, Brazil; *Corresponding Author: rsbarros@ufv.br

Received 22 December 2010; revised 12 January 2011; accepted 22 February 2011.

\begin{abstract}
The growth of seedlings of Townsville sytlo (Stylosanthes humilis H.B.K.) is inhibited by aluminium $(\mathrm{Al})$ ions, their elongation being recovered with sodium selenate at $1.0 \mu \mathrm{M}$. Methyl viologen and hydrogen peroxide, reactive oxygen species (ROS)-generating compounds, also inhibited seedling elongation and again growth was relieved by selenate. Selenate, thus, seemed to be operating as a ROS quencher, since $\mathrm{N}$-acetylcysteine (NAC), an antioxidant compound, also stimulated largely the growth of Al-inhibited seedlings. At a higher concentration (0.1 $\mathrm{mM})$, however, selenate inhibited seedling growth and elongation was recovered by NAC. Ethylene production by selenate plus NAC-treated seedlings was very higher and thus the gaseous hormone was not responsible for the seedling growth inhibition caused by selenate. Hence, it seems that at high levels selenate operates as a ROS-generating compound whose effects were counteracted by NAC. It can be deduced that, at low concentration, selenate behaves as a ROS quencher and at high level as a ROS-promoting species.
\end{abstract}

Keywords: Aluminium; Ethylene; Growth Inhibition; Reactive Oxygen Species; Selenate; Townsville Stylo

\section{INTRODUCTION}

Plant growth is greatly affected by several environmental stresses such as drought, extreme temperatures and heavy metals. On acidic soils Al toxicity has been recognized as a major limiting factor of plant productivity [1]. Plants can respond and adapt to Al stress by altering their cellular metabolism and invoking various defense mechanisms [2]. Usually Al toxicity induces accumulation of reactive oxygen species (ROS), that have been established as key signalling molecules controlling a diverse range of physiological functions $[3,4]$. However, at high concentrations and in certain situations, ROS may be toxic [5].

Since the effects of reactive oxygen molecules at cellular level is mediated by their production and removal via antioxidant activity [6], the use of free radical quenchers may help to identify the role of ROS in plant systems. Selenium (Se) is interesting in this matter because in response to oxidative stresses, Se compounds at low concentrations, perform a protective function by scavenging free radicals $[7,8]$. On the other hand, excess Se can cause damage to plants, likely by triggering ROS generation $[9,10]$. This antagonistic property makes Se unique in studies dealing with systems requiring ROS to elicit a physiological response.

Toxicity caused by Se compounds is an ill-understood phenomenon [11]. There are indications that at high levels Se can indiscriminately replace $\mathrm{S}$ in certain aminoacids that are incorporated into proteins [11,12]. The formation of Se-aminoacids, in turn, is supposed to enhance ethylene production [13], which can cause damages to plant growth. Some biochemical and physiological studies were conducted with Se-compounds in plant systems $[8,14,15]$, but no physiological co-action between $\mathrm{Se}$ and $\mathrm{Al}$ has been stablished. In this work the effects of Se at low concentration added to the growth medium as a protector against $\mathrm{Al}$ toxicity were investigated. Furthermore, the mode of action of Se, at high concentration, on seedling growth of Townsville stylo was also examined. The experiments were performed with seedlings of Townsville stylo, an annual forage legume cultivated in tropical pastures [16]. The species has been considered as a potential contributor for pasture improvement in tropical zones due to its high-quality forage for livestock, high seed production and wide adaptability to low fertility soils [17]. 


\section{MATERIALS AND METHODS}

\subsection{Plant Material and General Conditions}

Seeds of Townsville stylo (Stylosanthes humilis H.B.K.) were obtained from plants cultivated in $3.5 \mathrm{~L}$ plastic pots in a greenhouse in Viçosa $\left(20^{\circ} 45^{\prime} \mathrm{S}, 42^{\circ} 15^{\prime} \mathrm{W}\right)$, Minas Gerais, Brazil and kept in the laboratory under dry conditions. Non-dormant seeds were freed from their husks, scarified with fine sandpaper $\left(\mathrm{n}^{\circ} 150\right)$, sterilized with 0.5 $\% \mathrm{NaOCl}$ for $10 \mathrm{~min}$, and thoroughly washed with distilled water. Seeds were taken to $15 \mathrm{~cm}$ diameter Petri dishes with two layers of Whatman $\mathrm{n}^{\mathrm{o}} 1$ filter paper and $16 \mathrm{ml}$ of distilled water $(\mathrm{pH} 7.0)$. This assembly was placed in the dark in a day/night growth chamber (Forma Scientific Inc, Ohio, USA), at $30^{\circ} \mathrm{C}$, for $18 \mathrm{~h}$. Afterwards, germinated seeds with a protruded radicle about $3 \mathrm{~mm}$ long were transferred to $9 \mathrm{~cm}$ diameter Petri dishes with two layers of filter paper, and incubated with $10 \mathrm{ml}$ test solutions. Solutions were prepared by dissolving chemicals in $0.5 \mathrm{mM} \mathrm{CaCl}_{2}$ solution, $\mathrm{pH} 4.0$, a condition that prevents proton toxicity and leads to separation of the effects of proton toxicity from the effects of Al toxicity [18]. After $24 \mathrm{~h}$ exposure period, root and hypocotyl lengths of the seedlings were determined.

\subsection{Se Effects on Growth}

Sodium selenate $\left(\mathrm{Na}_{2} \mathrm{SeO}_{4}\right)$ was chosen as to represent the several soluble Se compounds whose effects on dormancy breakage of Townsville stylo seeds are all identical [14]. The effects of $\mathrm{Na}_{2} \mathrm{SeO}_{4}$, at low concentration $(1 \mu \mathrm{M})$, on Al-treated seedling were examined by providing the compound to seedlings in the solutions of $\mathrm{AlCl}_{3}(1.0,1.5$ and $2 \mathrm{mM})$. In order to assess for a causal association between Al-induced ROS production and growth inhibition, seedlings were also exposed to combined solutions of $\mathrm{AlCl}_{3}$ plus $\mathrm{N}$-acetylcysteine (NAC, 1 $\mathrm{mM}$ ), a free-radical quenching compound. Seedlings were also exposed to solution of methyl viologen (MV, $10^{-7}$ $\left.10^{-4} \mathrm{M}\right)$ and $\mathrm{H}_{2} \mathrm{O}_{2}\left(10^{-7}-10^{-4} \mathrm{M}\right)$, ROS-inducing substances, alone or to each one combined with $\mathrm{Na}_{2} \mathrm{SeO}_{4}$. To investigate the effects of the exposure order seeds were treated witch a combined solution of $\mathrm{AlCl}_{3}$ plus $\mathrm{Na}_{2} \mathrm{SeO}_{4}, \mathrm{AlCl}_{3}$ or $\mathrm{Na}_{2} \mathrm{SeO}_{4}$ for the first $6 \mathrm{~h}$. $\mathrm{AlCl}_{3}$ solutions was then replaced by $\mathrm{Na}_{2} \mathrm{SeO}_{4}$ and $\mathrm{AlCl}_{3} ; \mathrm{Na}_{2} \mathrm{SeO}_{4}$ solutions by $\mathrm{AlCl}_{3}$; seeds were kept in the new media for $18 \mathrm{~h}$.

In order to search for the effects of $\mathrm{Na}_{2} \mathrm{SeO}_{4}$ at high concentration $(0.1 \mathrm{mM})$ on seedling growth and ethylene production, Se-treated seedlings were also provided with 2-aminoethoxyvinylglycine (AVG, $10 \mu \mathrm{M}$ ) solution, an inhibitor of ethylene biosynthesis. A putative relationship between high $\mathrm{Na}_{2} \mathrm{SeO}_{4}$ concentration-induced ROS generation and inhibition of seedling growth was also searched for with the employment of NAC (1 mM).

\subsection{Root Cell Viability}

Cell viability was assessed by staining root tip fragments with fluorescein diacetate (FDA, $10 \mu \mathrm{M}$ ) and propidium iodide (PI, $2.0 \mu \mathrm{M}$ ), according to [19]. After treatment with test solutions, seedlings were washed with distilled water ( $\mathrm{pH}$ 7.0) and roots tips were stained for $5 \mathrm{~min}$ at room temperature with FDA and PI. The viability of cells was observed under a fluorescent microscope (BH2, Olympus, Japan).

\subsection{Ethylene Measurement}

For ethylene quantification Erlenmeyer flasks $(50 \mathrm{ml})$ containing 10 seedlings imbibed in $3 \mathrm{ml}$ test-solutions were stoppered with rubber serum caps and kept in the growth chamber, under the conditions previously described. Air samples $(1 \mathrm{ml})$ were taken from the flask headspace and injected in a gas chromatograph (Hewlett Packard 5890, Series II), equipped with a stainless-steel column $(1.0 \mathrm{~m} \times 6.0 \mathrm{~mm})$ packed with Porapak-N 80100 mesh. Ethylene quantitation was conducted under the following conditions: nitrogen carrier gas and hydrogen fluxes were $30 \mathrm{ml} \cdot \mathrm{min}^{-1}$; air flux was $320 \mathrm{ml} \cdot \mathrm{min}^{-1}$. Column, injector and detector temperatures were 60,110 and $150^{\circ} \mathrm{C}$, respectively. Ethylene peaks were registered by a peak simple software (Peak Simple, Version 3.92) coupled to the chromatograph, and quantified by comparison with authentic ethylene standards.

\subsection{Statistical Analysis}

The experiments followed a completely randomized design, with 10 replications per treatment. Experimental units consisted of a Petri dish or an Erlenmeyer flask with 10 seedlings. The Tukey test at $5 \%$ was applied to detect differences amongst means.

\section{RESULTS}

Aluminium inhibited root and hypocotyl growth of Townsville stylo seedlings in a dose-dependent manner (Figure 1). Inhibition of growth of Al-treated seedling was alleviated by $\mathrm{Na}_{2} \mathrm{SeO}_{4}$, at the low concentration employed. Growth recovery by $\mathrm{SeO}_{4}^{2-}$ was about $95 \%$, $81 \%$ and $66 \%$ in roots inhibited with $1.0,1.5$ and $2.0 \mathrm{mM}$ $\mathrm{Al}$ respectively. On the other hand, $\mathrm{SeO}_{4}^{2-}$ completely counteracted the growth inhibition of hypocotyl caused by Al. Selenate seemed to be operating through the quenching of ROS since NAC, an antioxidant compound, similarly recovered partially (roots) or completely (hypocotyls) the growth of Al-inhibited seedlings (Figure 1). Whether or not $\mathrm{Al}$ and $\mathrm{SeO}_{4}^{2-}$ were supplied to- 

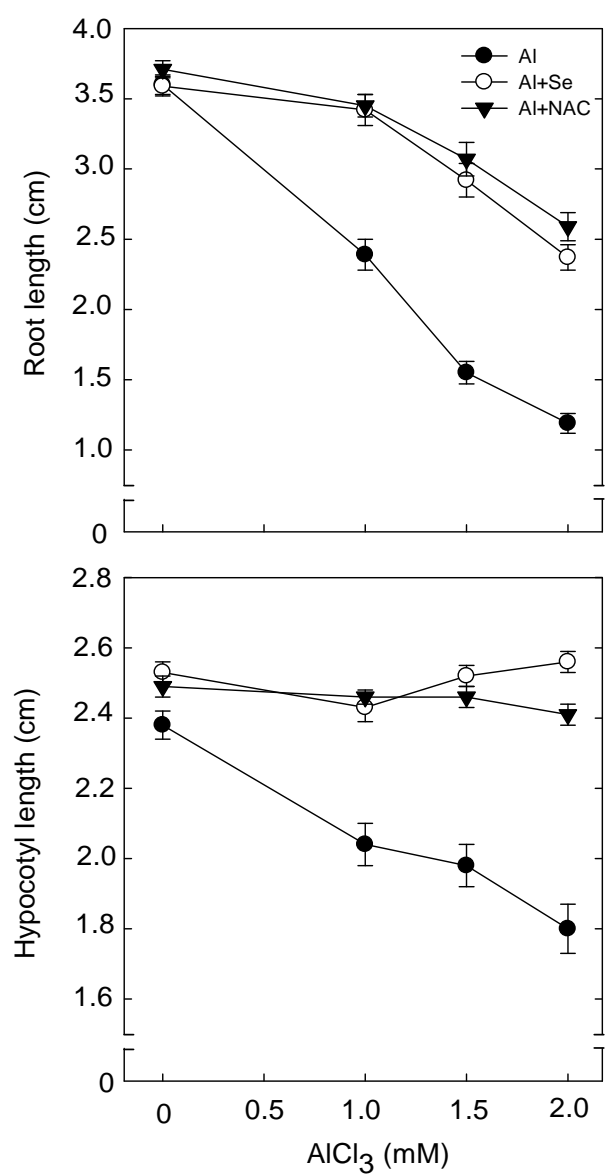

Figure 1. Se at low concentration alleviates $\mathrm{AlCl}_{3}$-induced inhibition of seedling growth. $\mathrm{AlCl}_{3}$ was provided to uniform seedlings in $0.5 \mathrm{mM} \mathrm{CaCl}_{2}$ soluton $\mathrm{pH} 4,0$ or combined with sodium selenate $(1 \mu \mathrm{M})$ and $N$-acetyl cisteine (NAC $1 \mathrm{mM}$ ). Means of 100 seedlings \pm standard errors.

gether or separately, one of them anteceding or following the supply of the other, their effects on seedling growth were very similar (Table 1). Vital staining also revealed differences in the response of seedlings treated with $\mathrm{Al}$ plus $\mathrm{SeO}_{4}^{2-}$ at low concentration (Figure 2). Aluminium caused considerable damage to root cells of Townsville stylo seedling. Selenate, on the other hand, caused substantial reduction in the $\mathrm{Al}$ damages to roots.

That $\mathrm{SeO}_{4}^{2-}$ seemed to be acting as an antioxidant leading to growth alleviation or restoration of seedling inhibited by $\mathrm{Al}$ was further demonstrated by treating seedling with $\mathrm{SeO}_{4}^{2-}$ and methyl viologen (MV) or $\mathrm{H}_{2} \mathrm{O}_{2}$. Similarly to the $\mathrm{Al}$ effects, $\mathrm{MV}$ and $\mathrm{H}_{2} \mathrm{O}_{2}$ inhibited root and hypocotyl elongation in a dose-dependent manner (Figure 3). Furthermore, $\mathrm{SeO}_{4}^{2-}$ restores $\left(\mathrm{H}_{2} \mathrm{O}_{2}\right)$ or alleviates (MV) the growth of inhibited roots; in hypocotyls $\mathrm{SeO}_{4}^{2-}$ completely overcame the inhibitory effects of both compounds. It is also observed that roots were much more sensitive to Al than hypocotyls (Figu-
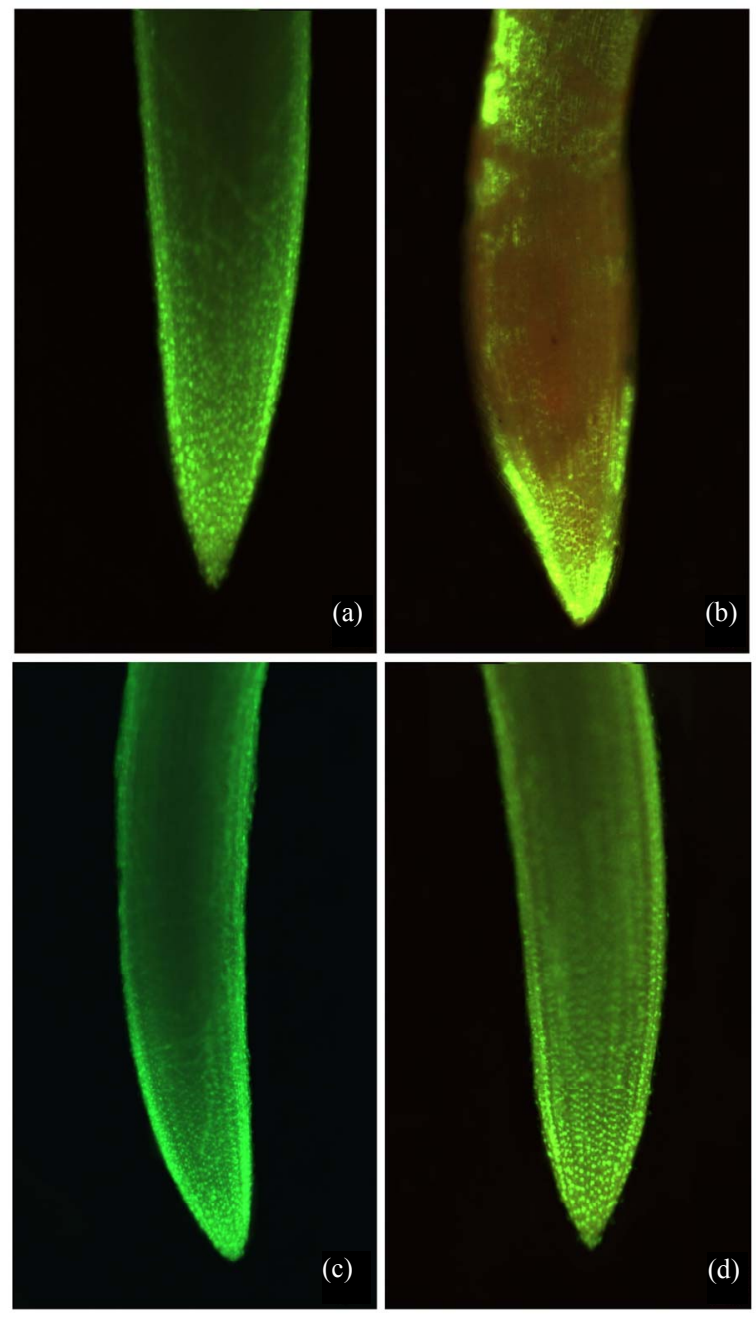

Figure 2. Protective effect of Se against Al-induced damages in root tips of Townsville stylo seedlings. (a) Control; (b) 2 $\mathrm{mM} \mathrm{AlCl} 3$; (c) $1 \mu \mathrm{M}$ sodium selenate; and (d) $\mathrm{AlCl}_{3}$ plus sodium selenate. Healthy cells exhibit green fluorescence due to fluorescein diacetate. Propidium iodide produces a red fluorescence of nuclei in damaged cells. Photos are representative of 5 replicates per treatment.

\section{res 1 and 3 ).}

The above results were completely different when $\mathrm{SeO}_{4}^{2-}$ was used in a high concentration $(0.1 \mathrm{mM})$, two orders of magnitude larger than the one employed to counteract the $\mathrm{Al}$ effects. At $0.1 \mathrm{mM}, \mathrm{SeO}_{4}^{2-}$ inhibited root and hypocotyl elongation by 48 and $21 \%$, respectively (Figure 4). As occurred with aluminium roots were shown to be much more sensitive to high Se level than hypocotyls. Selenate caused an increase in ethylene emanation by seedlings by about $89 \%$ (as compared to the control). The inhibitor of ethylene biosynthesis AVG substantially decreased ethylene production by seedlings treated with $\mathrm{SeO}_{4}^{2-}$, but without any effect on seedling growth (as compared to Se-treated seedlings alone). 


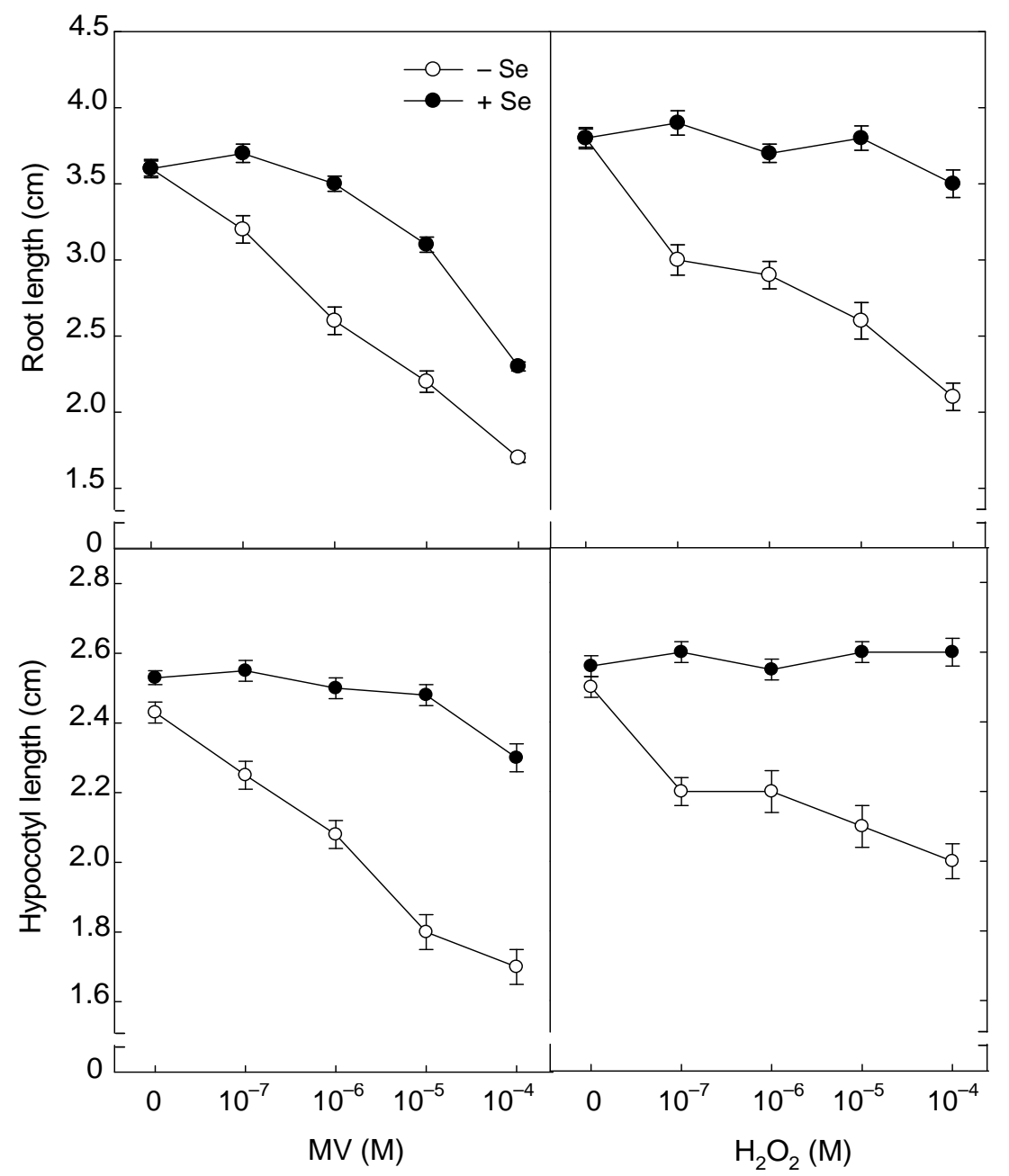

Figure 3. Effects of sodium selenate supplied with methyl viologen ( $\mathrm{MV}$, left) or $\mathrm{H}_{2} \mathrm{O}_{2}$ (right) solutions $\mathrm{pH} 4.0$ on seedling growth. Means of 100 seedlings \pm standard errors.

Hence ethylene seemed not to be required for growth inhibition of the $\mathrm{SeO}_{4}^{2-}$-treated seedlings (Figure 4). Selenate-induced inhibition of seedling growth was completely restored by NAC, but ethylene production by $\mathrm{SeO}_{4}^{2-}$-treated seedling was not decreased by the antioxidant compound, which actually showed to be very high (treatment $\mathrm{SeO}_{4}^{2-}$ plus NAC, Figure 4).

\section{DISCUSSION}

Growth inhibition is a well-known response of plants to toxic concentrations of $\mathrm{Al}$ ions [20]. The data described herein demonstrate that $\mathrm{SeO}_{4}^{2-}$, at low concentration $(1.0 \mu \mathrm{M})$, can alleviate partial or completely the Al-induced inhibition of root and hypocotyl elongation, respectively (Figure 1). Moreover, NAC, an antioxidant compound [21], was also capable of overcoming the inhibited state caused by Al. These results suggest that the $\mathrm{SeO}_{4}^{2-}$, at low concentration, may act as an antioxidant (possibly as a ROS quencher) to counteract inhibit- tion of root and hypocotyl elongation of Townsville stylo seedlings. In fact, Se can overcome oxidative damages displaying a protective effect against stressing conditions $[8,9]$. Selenate addition restored hypocotyl growth to the level of the control under any concentration of $\mathrm{Al}$ used. However, root growth inhibition by $\mathrm{Al}$ (at 1.5 and 2.0 $\mathrm{mM}$ ) was not recovered to the control level, indicating that roots were more sensitive to a toxic $\mathrm{Al}$ exposure than hypocotyls (see also Figure 3).

In order to get further insights into the relationships between $\mathrm{Al}$ and $\mathrm{SeO}_{4}^{2-}$ effects on the control of seedling growth, seedlings were treated with $\mathrm{Al}$ or $\mathrm{Al}$ plus $\mathrm{SeO}_{4}^{2-}$ (dissolved in $0.5 \mathrm{mM} \mathrm{CaCl}_{2}, \mathrm{pH} \mathrm{4.0)}$ ) for $24 \mathrm{~h}$ and afterwards transferred to the medium without Al. Seedling survival 10 days after transference was about $94 \%, 90 \%$, $30 \%$, and $80 \%$ if they were previously exposed to control $\left(0.5 \mathrm{mM} \mathrm{CaCl}_{2}, \mathrm{pH} 4.0\right), 1 \mu \mathrm{M} \mathrm{SeO}_{4}^{2-}, 2 \mathrm{mM} \mathrm{AlCl}_{3}$ and $\mathrm{AlCl}_{3}$ plus $\mathrm{SeO}_{4}^{2-}$, respectively (not shown). In keeping with those responses, Al toxicity effect was 

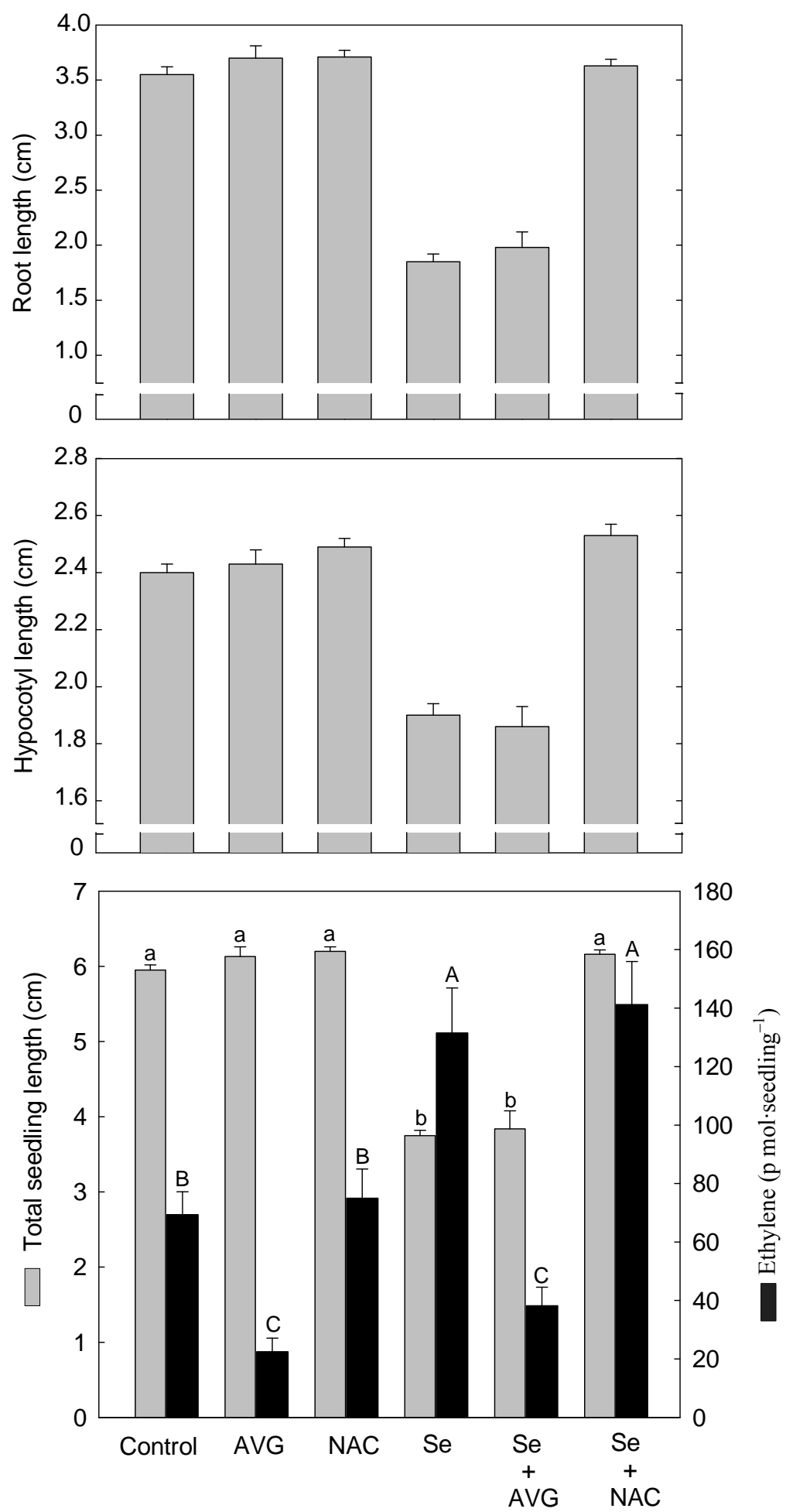

Figure 4. Ethylene production is not associated with growth inhibition of high selenium concentration-treated seedlings. AVG $(10 \mu \mathrm{M})$ and NAC $(1 \mathrm{mM})$ were provided to seedlings in a $\mathrm{CaCl}_{2}$ solution $\mathrm{pH} 4.0$ alone or also combined with sodium selenate $(0.1 \mathrm{mM})$. Means followed by the same small letter (seedling growth), or followed by the same capital letter (ethylene) do not differ significantly at $5 \%$ level. Data shown are means of 100 seedlings \pm standard errors. 
Table 1. Effects of $\mathrm{Na}_{2} \mathrm{SeO}_{4}$ provided alone or in combination with $\mathrm{AlCl}_{3}$ on the growth of seedlings of Townsville stylo. Sodium selenate $(1 \mu \mathrm{M}), \mathrm{AlCl}_{3}(2 \mathrm{mM})$ and sodium selenate plus $\mathrm{AlCl}_{3}$ were provided to seedlings in $0.5 \mathrm{mM} \mathrm{CaCl}_{2}$ solution $\mathrm{pH} 4.0$ for $6 \mathrm{~h}$ and then transferred to the next solutions (as indicated following the arrows) for $18 \mathrm{~h}$. In each column means do not differ significantly at $5 \%$ level, when followed by same letter. Means of 100 seedlings \pm standard errors.

\begin{tabular}{cccc}
\hline Treatment & Root length $(\mathrm{cm})$ & Hypocotyl length $(\mathrm{cm})$ & Seedling length $(\mathrm{cm})$ \\
\hline $\mathrm{Control} \rightarrow \mathrm{Control}$ & $3.8 \pm 0.09 \mathrm{a}$ & $2.4 \pm 0.04 \mathrm{a}$ & $6.2 \pm 0.10 \mathrm{a}$ \\
$\mathrm{Se} \rightarrow \mathrm{Se}$ & $3.6 \pm 0.08 \mathrm{a}$ & $2.5 \pm 0.04 \mathrm{a}$ & $6.1 \pm 0.10 \mathrm{a}$ \\
$\mathrm{AlCl}_{3} \rightarrow \mathrm{AlCl}_{3}$ & $1.2 \pm 0.07 \mathrm{c}$ & $1.8 \pm 0.05 \mathrm{~b}$ & $3.0 \pm 0.09 \mathrm{c}$ \\
$\mathrm{AlCl}_{3} \rightarrow \mathrm{Control}$ & $1.4 \pm 0.08 \mathrm{c}$ & $1.9 \pm 0.05 \mathrm{~b}$ & $3.3 \pm 0.11 \mathrm{c}$ \\
$\mathrm{AlCl}_{3} \rightarrow \mathrm{Se}$ & $2.4 \pm 0.10 \mathrm{~b}$ & $2.5 \pm 0.04 \mathrm{a}$ & $4.9 \pm 0.10 \mathrm{~b}$ \\
$\mathrm{Se} \rightarrow \mathrm{AlCl}_{3}$ & $2.7 \pm 0.12 \mathrm{~b}$ & $2.3 \pm 0.05 \mathrm{a}$ & $5.0 \pm 0.13 \mathrm{~b}$ \\
$\mathrm{AlCl}_{3}+\mathrm{Se} \rightarrow \mathrm{AlCl}_{3}+\mathrm{Se}$ & $2.4 \pm 0.11 \mathrm{~b}$ & $2.4 \pm 0.06 \mathrm{a}$ & $4.7 \pm 0.15 \mathrm{~b}$ \\
\hline
\end{tabular}

very high in seedling expose to $\mathrm{Al} 2 \mathrm{mM}$, as shown by vital staining of root tips (Figure 2). Selenate substantially reduced cell damages caused by Al, also diminishing the Al inhibition of root elongation, evidecing a protective role of Se. The inhibition relief of Al-treated seedling by $\mathrm{SeO}_{4}^{2-}$ was also observed had the seedlings been exposed to $\mathrm{SeO}_{4}^{2-}$ before $(\mathrm{Se} \rightarrow \mathrm{Al}$ ) or after (Al $\rightarrow \mathrm{Se}$ ) the Al supply (Table 1). Moreover, pre-treatment of seedlings with $\mathrm{SeO}_{4}^{2-}(\mathrm{Se} \rightarrow \mathrm{Al})$ or with $\mathrm{Al}(\mathrm{Al} \rightarrow$ Se) promoted a similar effect on root and hypocotyl elongation as the combined treatment with Al plus $\mathrm{SeO}_{4}^{2-}$. It follows that in short term Se is capable of impairing or repairing the damages caused by aluminium in the tissues.

A probable role of $\mathrm{SeO}_{4}^{2-}$, at low concentration, as an antioxidant agent to alleviate the Al-induced inhibition of seedling growth was also examined with the employment of $\mathrm{MV}$ and $\mathrm{H}_{2} \mathrm{O}_{2}$. MV, which generates singlet oxygen $\left(\mathrm{O}_{2}^{-}\right)$directly and $\mathrm{OH}^{*}$ radicals as secondary activated oxygen species $[22,23]$, and $\mathrm{H}_{2} \mathrm{O}_{2}$ constitute important tools for investigating the effects of activated oxygen species in biological systems. Similarly to the treatment with $\mathrm{Al}$, both $\mathrm{MV}$ and $\mathrm{H}_{2} \mathrm{O}_{2}$ reduced seedling growth and their inhibitory effect was substantially reversed by $\mathrm{SeO}_{4}^{2-}$, at the low concentration employed (Figure 3). These results suggest that the diminished action of oxygen species could explain the protective role of $\mathrm{SeO}_{4}^{2-}$ in Al-stressed plants.

The results point out to Se as exerting a dual effect on seedling growth process: at low concentration, it could act as an antioxidant enhancing growth of Al-inhibited seedlings, whereas at higher concentration it could act as a growth-inhibiting agent $[9,24]$. In fact, selenomethionine at high concentration inhibited seedling growth, as shown in [25], and several Se-soluble compounds elicited ethylene production by seeds and seedlings of Townsville stylo [14]. It is known that selenate at high levels, upregulates the genes coding for 1-aminocyclopropane-1-carboxylic acid (ACC) synthase and ACC oxidase, the two last enzymes in the pathway to ethylene biosynthesis [26]. Root elongation is also inhibited by ethylene [27] and thus it is likely that $\mathrm{SeO}_{4}^{2-}$, at high concentration, inhibits seedling growth through eliciting ethylene biosynthesis (Figure 4). However, AVG inhibited ethylene production of $\mathrm{SeO}_{4}^{2-}$-treated seedlings to a great extent, without any effect on seedling growth in comparison to seedlings treated with $\mathrm{SeO}_{4}^{2-}$ solely (Figure 4). These findings suggest that other mechanisms of action of $\mathrm{SeO}_{4}^{2-}$ at high concentrations, might be operative, which was supported with the use of NAC. When NAC was supplied to seedling together with $\mathrm{SeO}_{4}^{2-}$, seedling growth was increased to the level of the control and ethylene production stimulated by $\mathrm{SeO}_{4}^{2-}$ was not inhibited at all by NAC (Figure 4). Together these data provide evidence supporting that $\mathrm{SeO}_{4}^{2-}$-induced inhibition of seedling growth was likely associated with the action of ROS and not with ethylene production.

The results obtained on radicle growth of Towsville stylo seedlings are in contrast to those of bean, another legume [28], and Arabdopsis thaliana, a Brassicaceae [27]. In these species radicle growth is inhibited by the large amounts of ethylene induced by Al. In Arabidopsis the effects of ethylene were much reduced in the mutants etr-1 and ein-2, defective in ethylene signalling or with the use of $\mathrm{AVG}, \mathrm{Co}^{2+}$ and with $\mathrm{Ag}^{+}$, inhibitors of ethylene biosynthesis and action. By also employing the mutants aux1-7 and pin2, defective in auxin polar transport, and using naphthylphthalamic acid, winch disrupts the auxin polar transport, the inhibitory effects of $\mathrm{Al}$ in radicle growth were also greatly diminished or no longer observed. It was concluded that ethylene constitutes a signal which alters auxin distribution in roots by disrupting $A U X 1$ and PIN2-mediated auxin polar transport, causing an arrest in root elongation [29]. There remains, however, the possibility of a direct action of $\mathrm{Al}^{3+}$ in auxin distribution, thus bypassing the ethylene requirement, [29]. In this context, it can be conclused that the causes for inhibition of root growth are species-specific. 
In summary, the action of $\mathrm{SeO}_{4}^{2-}$ on seedling growth of Townsville stylo seedling was shown to depend on its concentration. At low concentration, it promotes the release of the Al growth inhibition, seeming to work as a scavenger of free radicals. At high concentrations, inhibition of seedling growth is not associated with a $\mathrm{SeO}_{4}^{2-}$-dependent ethylene biosynthesis, but seems associated to the ROS generation.

\section{ACKNOWLEDGEMENTS}

Thanks are due to FAPEMIG (Foundation for Research Support of Minas Gerais State) for the post-doctoral fellowship awarded to D.M.R. and for the financial support during the conduct of this research.

\section{REFERENCES}

[1] Delhaize, E. and Ryan, P.R. (1995) Aluminum toxicity and tolerance in plants. Plant Physiology, 107, 315- 321.

[2] Kochian, L.V., Hoekenga, O.A. and Pineros, M.A (2004) How do crop plants tolerate acid soils? Mechanisms of aluminium tolerance and phosphorous efficiency. Annual Review of Plant Biology, 55, 459-493. doi:10.1146/annurev.arplant.55.031903.141655

[3] Neill, S.J., Desikan, R. and Hancock, J.T. (2002) Hydrogen peroxide signalling. Current Opinion in Plant Biology, 5, 388-395. doi:10.1016/S1369-5266(02)00282-0

[4] Oracz, K., Bouteau, H,E.M., Farrant, J. M., Cooper, K., Belghazi, M., Job, C. et al. (2007) ROS production and protein oxidation as a novel mechanism for seed dormancy alleviation. The Plant Journal, 50, 452-465. doi:10.1111/j.1365-313X.2007.03063.X

[5] Bailey-Serres, J. and Mittler, R.M. (2006) The roles of reactive oxygen species in plant cells. Plant Physiology, 141, 331. doi:10.1104/pp.104.900191

[6] Carol, R. and Dolan, L. (2006) The role of reactive oxygen species in cell growth: Lessons from root hairs. Journal of Experimental Botany, 57, 1829-1834. doi:10.1093/jxb/erj201

[7] Seppänen, M., Turakainen, M. and Hartikainen, H. (2003) Selenium effects on oxidative stress in potato. Plant Science, 165, 311-319. doi:10.1016/S0168-9452(03)00085-2

[8] Filek, M., Keskinen, R., Hartikainen, H., Szarejko, I., Janiak, A., Miszalski, Z. et al. (2008) The protective role of selenium in rape seedlings subjected to cadmium stress. Journal of Plant Physiology, 165, 833-844. doi:10.1016/j.jplph.2007.06.006

[9] Hartikainen, H., Xue, T. and Piironen, V. (2000) Selenium as an antioxidant and pro-oxidant in ryegrass. Plant and Soil, 225, 193-200. doi:10.1023/A:1026512921026

[10] Mora, M., Pinilla, L., Rosas, A. and Cartes, P. (2008) Selenium uptake and its influence on the antioxidative system of white clover as affected by lime and phosphorus fertilization. Plant and Soil, 303, 139-149. doi:10.1007/s11104-007-9494-Z

[11] Brown, T.A. and Shrift, A. (1982) Selenium: Toxicity and tolerance in higher plants. Biological Review, 57, 59-84. doi:10.1111/j.1469-185X.1982.tb00364.x
[12] Eustice, D.C., Kull, F.J. and Shrift, A. (1981) Selenium toxicity: Aminoacylation and peptide bond formation with selenomethionine. Plant Physiology, 67, 1054- 1058. doi:10.1104/pp.67.5.1054

[13] Konze, J.R., Schilling, N. and Kende, H. (1978) Enhancement of ethylene formation by selenoamino acids. Plant Physiology, 62, 397-401. doi:10.1104/pp.62.3.397

[14] Pinheiro, F.J.A., Barros, R.S., Coelho, T.G. and Souza, B. M.L. (2008) Breaking dormancy of Stylosanthes humilis seeds with selenium compounds. Seed Science Research, 18, 47-53. doi:10.1017/S0960258508890253

[15] Feng, R., Wei, C., Tu, S. and Sun, X. (2009) Interactive effects of selenium and arsenic on their uptake by Pteris vittata L. under hydroponic conditions. Environmental and Experimental Botany, 65, 363-368. doi:10.1016/j.envexpbot.2008.11.013

[16] Williams, R.J., Reid, R., Schultze-Kraft, R., Souza Costa, N.M. and Thomas, B.D. (1984) Natural distribution of Stylosanthes. In: Stace, H.M. and Edye, L.A. Eds., The Biology and Agronomy of Stylosanthes, Academic Press, Sydney, 73-110.

[17] Gardner, C.J. (1984) The Dynamics of Stylosanthes Pastures. In: Stace, H.M. and Edye, L.A. Eds., The Biology and Agronomy of Stylosanthes, Academic Press, Sydney, 333-357.

[18] Rangel, A.F., Mobin, M., Rao, I.M. and Horst, W.J. (2005) Proton toxicity interferes with the screening of common bean (Phaseolus vulgaris L.) genotypes for aluminium resistance in nutrient solution. Journal of Plant Nutrition and Soil Science, 168, 607-616. doi:10.1002/jpln.200520509

[19] Jones, K.H. and Senft, J.A. (1985) An improved method to determine cell viability by simultaneous staining with fluorescein diacetate-propidium iodide. Journal of Histochemistry and Cytochemistry, 33, 77-79. doi: $10.1177 / 33.1 .2578146$

[20] Jones, D.L., Blancaflor, E.B., Kochian, L.V. and Gilroy, S. (2008) Spatial coordination of aluminium uptake, production of reactive oxygen species, callose production and wall rigidification in maize root plant. Plant Cell and Environment, 29, 1309-1318. doi:10.1111/j.1365-3040.2006.01509.x

[21] Lobréaux, S., Thoiron, S. and Briat, J.-F. (1995) Induction of ferritin synthesis in maize leaves by an iron-mediated oxidative stress. The Plant Journal, 8, 443-449. doi:10.1046/j.1365-313X.1995.08030443.x

[22] Babbs, C.F., Phan, J.A. and Coolbaugh, R.C. (1989) Lethal hydrogen radical production in paraquat-treated plants, Plant Physiogy, 90, 1267-1270. doi:10.1104/pp.90.4.1267

[23] Foyer, C.H., Lelandais, M. and Kunert, K.J. (1994) Photooxidative stress in plants. Physiologia Plantarum, 92, 696-717. doi:10.1111/j.1399-3054.1994.tb03042.x

[24] Xue, T., Hartikainen, H. and Piironen, V. (2001) Antioxidative and growth-promoting effect of selenium on senescing lettuce. Plant and Soil, 237, 55-61. doi:10.1023/A:1013369804867

[25] Barros, R.S. and Freitas, A.W.P. (2001) Selenomethionine as a dormancy-breaking agent in seeds of Stylosanthes humilis. Acta Physiologicae Plantarum, 23, 279-284. doi:10.1007/s11738-001-0034-9 
[26] Hoewyk, D.V., Takahashi, H., Inoue, E., Hess, A., Tamaski, M. and Pilon-Smits, E.A.H. (2008) Transcriptome analyses give insights into selenium-stress responses and selenium tolerance mechanisms in Arabidopsis. Physiologia Plantarum, 132, 236-256.

doi:10.1093/pcp/pcm077

[27] Sun, P., Tian, Q.-Y., Zhao, M.G., Dai, X.Y., Huang, J.H., Li, L.H. et al., (2007) Aluminum-induced ethylene production is associated with inhibition of root elongation in lotus japonicus L. Plant and Cell Physiology, 48,
1229-1235.

[28] Massot, N., Nicander, B., Barcelo, J., Poschenrieder, C.H. and Tillberg, E. (2002) A rapid increase in cytokinin levels of root growth in bean seedlings (Phaseolus vulgaris L). Plant Growth Regulation, 37, 105-112. doi:10.1023/A:1020511007138

[29] Sun, P., Tian, Q.-Y., Chan, J. and Zhang, W.-H. (2010) Aluminium-induced inhibition of root elongation in Arabidopsis is mediated by ethylene and auxin. Journal of Experimental Botany, 61, 347-356. 